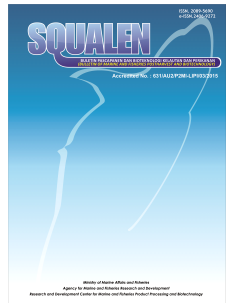

www.bbp4b.litbang.kkp.go.id/squalen-bulletin

\title{
Squalen Bulletin of Marine and Fisheries Postharvest and Biotechnology
}

ISSN: 2089-5690

e-ISSN: 2406-9272

\section{PREVALENCE OF AFLATOXIN B1 IN COMMERCIAL DRIED FISH FROM SOME REGIONS OF JAVA}

\author{
Ninoek Indriati ${ }^{\star *}$, Irma Hermana', Izhamil Hidayah' and Endang S. Rahayu ${ }^{2}$ \\ ${ }^{1}$ Research and Development Center for Marine and Fisheries Product Processing and Biotechnology, \\ Ministry of Marine Affairs and Fisheries, Jalan K.S. Tubun Petamburan VI, Jakarta, 10260, Indonesia \\ ${ }^{2}$ Faculty of Agricultural Technology, Universitas Gadjah Mada \\ Article history: \\ Received: 10 August 2017; Revised: 30 September 2017; Accepted: 30 December 2017
}

\begin{abstract}
The purpose of this study is to study the prevalence of aflatoxin B1 in commercial dried salted fish and other related information. A total of 150 samples were classified into 3 groups, based on the salt content. Low salt content $(0-5 \%)$ were dried anchovies (Stolephorus sp.) and commerson's anchovy (Stolephorus commersonii); moderate salt content (6-10\%) were medan anchovy (Stolephorus bataviensis) and whipfin silverbiddy (Gerres filamentosus) while high salt content (>10\%) were moonlight gouramy (Trichogaster microlepis) and snakehead fish (Channa striata). The samples were collected from different seller in Java Island and then determined for Aspergillus flavus, Aflatoxin B1, salt content, moisture content, $\mathrm{pH}$, water activity and total mold count. Results showed that dried salted fish were contaminated with $A$. flavus at temperature of $25.2-32.2{ }^{\circ} \mathrm{C}, 65-84 \%$ humidity, $17-50 \%$ moisture content, $0.25-19.88 \%$ salt content, and $0.73-0.86 \mathrm{a}_{\mathrm{w}}$. The prevalence of $A$. flavus in dried salted fish was $9.33 \%(14 / 150)$ and the prevalence of aflatoxin B1 was $8 \%(12 / 150)$ with detectable concentrations of $10.71-33.6 \mathrm{ppb}$.
\end{abstract}

Keyword: aflatoxin B1, Aspergillus flavus, dried salted fish

\section{Introduction}

Dried salted fish processing is one of fish preservation method that is widely practiced in Indonesia. Unfortunately, the processing of salted fish generally is still lack of sanitation and hygiene. This resulted poor quality of salted fish product. In addition, dried salted fish experienced poor storage condition during distribution either in processors, wholesalers or retailers (Indriati et al., 2016). Dried salted fish are stored using sacks or boxes and piled in traditional storage. At the wholesaler, storage of dried salted fish is generally better than that at the producer or retailer. Some wholesalers keep the fish in cold storage, so that the quality of dried salted fish is better and can be stored in longer period. At the retailer, dried salted fish are usually stacked in cartons boxes, or in bamboo container and arranged vertically, so that look like a mountain (usually for small fish like anchovies). These conditions cause the area under a pile of it being warm or hot, which allows the mold to grow (Rahayu, Sardjono, \& Samson, 2014). On the condition that dried salted fish have low water activity and moisture content, mold can grow. The types of mold commonly found are Aspergillus sp. and Penicillium sp. Wheeler, Hurdman, \& Pitt (1991) reported A. flavus was found in some samples of dried salted fish purchased from markets in Indonesia, although aflatoxin was not found in those samples. Rahayu et al. (2014) reported that $A$. flavus can be found in nuts, corn, cereals and seeds containing oil. Research on dried salted, boiled salted and smoked fish by Indriati et al. (2015) indicated the presence of $A$. flavus in dried salted fish was $7.2 \%$, smoked fish $11.2 \%$ and boiled salted fish $2.4 \%$ of the total 150 samples.

The growth of $A$. flavus is largely influenced by various factors including the composition of the substrates, moisture, humidity and temperature (Mishra \& Das, 2003). Makfoed (1993) reported that

${ }^{*}$ Corresponding author

E-mail: indriati_ninoek@yahoo.co.id 
A. flavus has an ability to grow in a wide temperature range and can be mesophilic or thermophilic. The temperature range of $A$. flavus for growth is at 10$48^{\circ} \mathrm{C}$. In addition to temperature, water activity also affects the growth of $A$. flavus where the optimum temperature for A.flavus growth is 33 and $25^{\circ} \mathrm{C}$ at $\mathrm{a}_{\mathrm{w}}$ of at 0.78 and 0.84 respectively (Pitt \& Hocking, 2009).

Aflatoxins B1 and B2 are secondary metabolites produced by $A$. flavus. Among the types of aflatoxins, aflatoxin $B 1$ is the most toxic. This compound is toxic to both animal and human. In addition, aflatoxins B1 is also immunosuppressive which can affect immunity (Duniaji, Hapsari, \& Puspawati, 2016). High level exposure of aflatoxin to human body will increase the risk of hepatocellular carcinoma three times greater than those who are not subject to exposure (Yenie, 2006). A high concentration of aflatoxins can cause acute illness and death, whereas low concentrations in the long term can cause necrosis of liver and kidney cells (Didwaina \& Joshi, 2013).

Aflatoxin B1 can be analysed using HPLC, TLC, LC/MS or enzym-linked immunosorbent assay (ELISA). ELISA method potentially have advantages over the other procedures due to their simplicity, sensitivity, low cost and the use of safe reagents. Extensive studies on aflatoxins in foods have validated that ELISA is very accurate, but expensive compared to low throughput research-oriented techniques, such as HPLC and LC/MS (Chun, Kim, Hwang, \& Chung, 2007, Chiou, Miller, Wilson, Trail, \& Linz, 2002, Gunterus, Roze, Beaudry, \& Linz, 2007). ELISA method have been used for aflatoxin determination to monitor contamination effectively in large quantities of sample (Ayejuyo et al., 2011).

The aims of this research was to determine the prevalence of $A$. flavus and flatoxin B1 in commercial dried fishes.

\section{Materials and Methods}

\subsection{Sample Collection}

A total of 150 samples of dried salted fish were collected from different regions of Java Island (Banten, DKI Jakarta, West Java, Central Java and East Java). Samples were grouped based on the salt content. Low salt content (0-5\%): anchovy (Stolephorus sp.) and whipfin silverbiddy (Gerres filamentosus), moderate salt content (6-10\%): commerson's anchovy (Stolepohorus commersonii) and medan anchovy (Stolephorus bataviensis), high salt content $(>10 \%)$ : moonlight gouramy (Trichogaster microlepis) and snakehead fish (Channa striata). To determine the environmental condition of sample storage, measurement of temperature and humidity were done at the time of sampling.

\subsection{Isolation and Screening of Aspergillus flavus}

A. flavus were isolated from dried salted fish using pour plate method on Aspergillus Flavus Parasiticus Agar (AFPA) media (Pitt, Hocking, \& Glenn, 1983 and Corry, Curtis, \& Baird, 2003). Twenty five grams of sample were added to $225 \mathrm{ml}$ of sterile ButterField Phosphate (BFP) and blended for $1 \mathrm{~min}$. An appropriate dilution was prepared in $9 \mathrm{ml}$ of BFP, $1 \mathrm{ml}$ of each dilution was poured into a sterile petridish followed by AFPA media. Cultures were then incubated at 25$30^{\circ} \mathrm{C}$ for $24-48 \mathrm{~h}$. A. flavus produce an orange yellow reserve colony pigmentation.

\subsection{Analysis of Aflatoxin B1}

Determination of aflatoxin B1 concentration in the sample was carried out by enzyme linked immunosorbent assay (ELISA) method using ELISA kit comersial AgraQuant. A total of $20 \mathrm{~g}$ of sample was blended with $100 \mathrm{ml}$ of methanol water (70:30) for 3 minutes. Then the supernatant was filltered using Whatman no. 1 and the filtrate was adjusted to $\mathrm{pH}$ of 6-8. Then $100 \mu \mathrm{l}$ filtrat added with $100 \mu \mathrm{l}$ buffer ELISA kit and carried out ELISA test. Standard solutions of AFB1 were prepared at $0,2,5,20$, and $50 \mathrm{ppb}$. Furthermore, the absorbance of microwell was read with ELISA reader at wavelength $(\lambda) 450 \mathrm{~nm}$ in 10 minutes. Aflatoxin concentration was determined by the formula:

$\% \mathrm{~B} / \mathrm{BO}=\frac{\text { sample or standard absorbance } \times 100 \%}{\text { blank absorbance }(0 \mathrm{ppb} \text { standard })}$
$\mathrm{B}=$ standard absorbance
$\mathrm{BO}=$ blank absorbance

As supporting data, analysis of moisture content (BSN, 2006), salt content (BSN, 1991), pH (AOAC, 2006), water activity $\left(a_{w}\right)\left(a_{w}\right.$ sprint TH 500 instrument (Novasina)) and total mold count (BSN, 2009) were carried out. In addition, measurement of temperature and environment humidity were also carried out during sampling of dried fish.

\section{Results and Discussion}

Table 1 describes some information about the characteristics of salted fish species tested in the experiment. The salted fish species was grouped 
Table 1. Aw, water content, salt content, $\mathrm{pH}$, total mold of several dried fish at certain temperature and humidity

\begin{tabular}{|c|c|c|c|c|c|c|c|c|}
\hline Sample & $\mathbf{n}$ & $a_{w}$ & $\begin{array}{l}\text { Moisture } \\
\text { Content } \\
\text { (\%) }\end{array}$ & $\begin{array}{c}\text { Salt } \\
\text { Content } \\
\text { (\%) }\end{array}$ & $\mathrm{pH}$ & $\begin{array}{l}\text { Total Mold } \\
(\log \mathrm{cfu} / \mathrm{g})\end{array}$ & $\begin{array}{c}\text { Temperature } \\
\left({ }^{\circ} \mathrm{C}\right)\end{array}$ & Hum idity \\
\hline $\begin{array}{l}\text { Anchovies } \\
\text { (Stolephorus sp.) }\end{array}$ & 25 & $0.597-0.846$ & $11.59-44.72$ & $0.07-2.04$ & $5.44-6.65$ & $1-2.23$ & $29.8-34.9$ & $40-76$ \\
\hline $\begin{array}{l}\text { Whipf in silverbiddy } \\
\text { (Gerres filamentosus) }\end{array}$ & 25 & $0.598-0.855$ & $14.26-42.52$ & $0.47-3.88$ & $5.62-7.92$ & $0.7-3.36$ & $29-33.8$ & $42-78$ \\
\hline $\begin{array}{l}\text { Commerson's anchovy } \\
\text { (Stolepohorus } \\
\text { commersonii) }\end{array}$ & 26 & $0.555-0.822$ & $17.78-64.66$ & $6.21-10.22$ & $5.47-6.62$ & $1-3.67$ & $29.7-33.8$ & $40-76$ \\
\hline $\begin{array}{l}\text { Medan anchovy } \\
\text { (Stolephorus bataviensis) }\end{array}$ & 28 & $0.593-0.842$ & $42.42-67.75$ & $5.51-10.20$ & $5.91-7.10$ & $0.7-2.67$ & $29-33.6$ & $40-78$ \\
\hline $\begin{array}{l}\text { Moonlight gouramy } \\
\text { (Trichogaster microlepis) }\end{array}$ & 24 & $0.588-0.809$ & $27.92-54.31$ & $10.39-18.81$ & $5.34-6.89$ & $0.7-2.0$ & $30.8-34.9$ & $40-66$ \\
\hline $\begin{array}{l}\text { Snakehead Fish } \\
\text { (Channa striata) }\end{array}$ & 27 & $0.590-0.799$ & $24.77-54.07$ & $9.69-15.20$ & $5.44-6.44$ & $0.7-3.98$ & $29-34.9$ & $40-78$ \\
\hline
\end{tabular}

based on the level of salt content identified in fish samples. Achovies and whipfin silverbiddy have a range of salt level at $0-5 \%$, commerson's anchovies and medan anchovy at $5-10 \%$ and moonlight gouramy and snakehead fish at $10 \%$ which were categorized as low, moderate and high salinity fishes, respectively.

The results showed that 14 of total 150 samples were contaminated by $A$. flavus. The environmental condition such as temperature and $\mathrm{a}_{\mathrm{w}}$ allows the mold to grow. Among the 14 samples contaminated with $A$. flavus, 12 samples produced AFB1. A. flavus are often found in other fish processing products. Salting was aimed to reduced moisture content and mold contamination in food, but some types of mould can grow and produce toxin in diverse environmental conditions (Ismail, 2013). Indriati, Supriyadi and Salasa, (2008) found $A$. flavus in boiled salted fish, while Basmal, Indriati, Hak, and Nasran (1999) found the mold in natural fermentation of smoked-skipjack (arabushi). Safika (2008) reported that there was a significant correlation between the presence of $A$. flavus and concentration of AFB1 in arabushi. She found that $100 \%$ of arabushi sample infested by $A$. flavus with concentration of $1-61 \times 10^{2} \mathrm{cfu} / \mathrm{g}$ and AFB1 of 0,9-38.7 ppb. In our study, dried salted fish were contaminated with $A$. flavus at temperature of 25.2$32.2^{\circ} \mathrm{C}, 65-84 \%$ humidity, $17-50 \%$ moisture content, $0.25-19.88 \%$ salt content, and 0.73-0.86 $\mathrm{a}_{\mathrm{w}}$. This condition is in accordance with study conducted by Pitt and Hocking (2009) that $A$. flavus can grow at temperature of $10-48^{\circ} \mathrm{C}$ with the optimum temperature of $33^{\circ} \mathrm{C}$. A. flavus produces aflatoxin at temperature range of $13-37{ }^{\circ} \mathrm{C}$ and at $0.78 \mathrm{a}_{\mathrm{w}}$. The optimum temperature of aflatoxin production was $16-31^{\circ} \mathrm{C}, 0.95-$ $0.99 \mathrm{a}_{\mathrm{w}}$ (ICMSF, 1996).

In Figure 1, Whipfin silverbiddy (low salt content dried fish) had the highest prevalence of $A$. flavus $(16 \%)$ compared to medium and high salt content dried fish with concentration of 1.00-1.70 log cfu /g (Table 2).

Figure 2 showed the highest prevalence of aflatoxin B1 was 16\%; which was found in fish with low salt content. Interestingly, the highest concentration of AFB was found in fish with moderate salt content with 27.43-30.00 and 27.66-31.20 ppb (Table 2).

Figure 3. showed that the highest prevalence level of A.flavus (16\%, at concentration of $1.7 \mathrm{log} \mathrm{cfu} / \mathrm{g}$ ) was found on dried salted fish with low salt content $(0-5 \%)$ compared to those of moderate $(6-10 \%)$ and high salt content $(>10 \%)$. Moreover, the prevalence of AFB1 at low salt content of dried fish (unsalted anchovies) was also the highest $(16 \%$, at concentration of $33.56 \mathrm{ppb}$ ) compared to medium and high salted products. This condition indicates that the salt content of dried fish affected the growth of $A$.flavus and the production of AFB1. Among the 14 samples contaminated with $A$. flavus, 12 samples produced AFB1 with detectable concentrations of 10.71-33.6 $\mathrm{ppb}$. There is no regulation regarding the maximum limit of AFB1 in dried fish. Dharmaputra, Putri, Retnowati, and Ambarwati (2003) reported that the maximum limit of AFB1 for corn and nuts in Indonesia was $20 \mathrm{ppb}$, while Rahayu and Khotimah (2010) reported that the standard of AFB1 for nuts and corn 


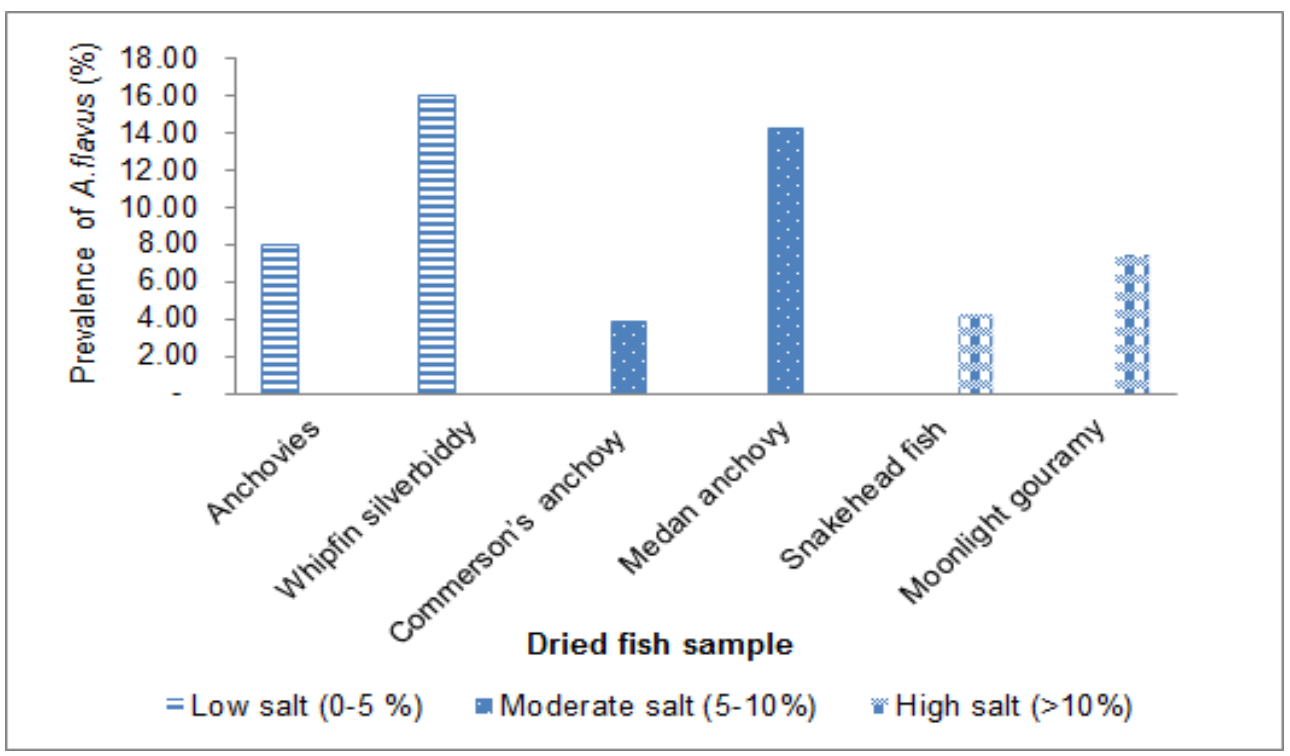

Figure 1. Prevalence of $A$. flavus from dried salted fish.

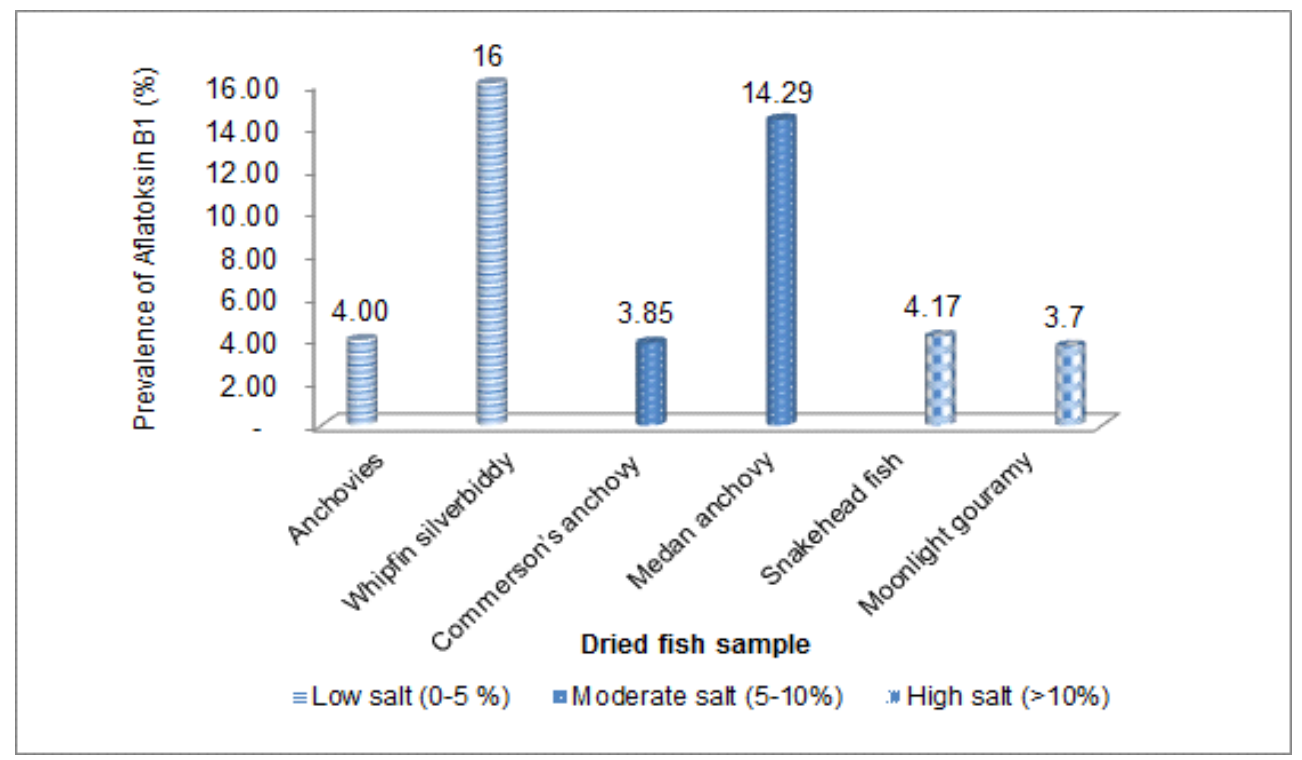

Figure 2. Prevalence of AFB1 from dried salted fish.

is $15 \mathrm{ppb}$. Duniaji et al. (2002) in Safika (2008) reported that in Bali, $32.6 \%$ of foods made from peanuts, rice and coconuts sold in markets and supermarkets were contaminated with aflatoxins with concentration exceeding WHO standard (20 ppb).

In this study, there was no correlation between concentration and prevalence of $A$. flavus, especially on medium and high salt levels. This is likely due to the growth of $A$. flavus influenced by the concentration of salt. Attapattu \& Sarajeewa (1990) reported that the growth of A.flavus was inhibited in salt concentration of $>10 \%$. It seems that there was a positive correlation between $A$. flavus and AFB1 on dried fish with low and moderate salt content, but it was negative in high salt content. Pitt and Hocking (2009) said that not all species of $A$. flavus produces AFB1. Rahayu et al. (2014) reported that $A$. flavus in different species of fish can contain different values and concentration of AFB1.

The prevalence of $A$. flavus in dried salted fish at retailer was higher than that at wholesaler and producer (Figure 4). This was happened because the environmental conditions are easily contaminated with other commodities, thus it was vulnerable to mold contamination from beans or corn that sold at the same market. This phenomenon agrees with Wang \& 
Table 2. Concentration of $A$. flavus in dried salted fish

\begin{tabular}{lcc}
\hline \multicolumn{1}{c}{ Samples } & $\begin{array}{c}\text { Total A. flavus } \\
(\mathbf{l o g} \text { cfu/g) }\end{array}$ & $\begin{array}{c}\text { Concentration range } \\
\text { of AFB1 (ppb) }\end{array}$ \\
\hline Anchovies (Stolephorus sp.) & $1.00-1.70$ & $6.50-8.00$ \\
Whipfin silverbiddy (Gerres filamentosus) & $1.00-1.70$ & $10.71-34.50$ \\
Commerson's anchovies (Stolepohorus commersonii) & 1.00 & $27.43-30.00$ \\
Medan anchovy (Stolephorus batavie) & 1.00 & $27.66-31.20$ \\
Snakehead fish (Trichogaster microlepis) & $1.00-1.78$ & $16.00-20.020$ \\
Moonlight gouramy (Channa striata) & $1.00-1.60$ & $24.60-27.00$ \\
\hline
\end{tabular}

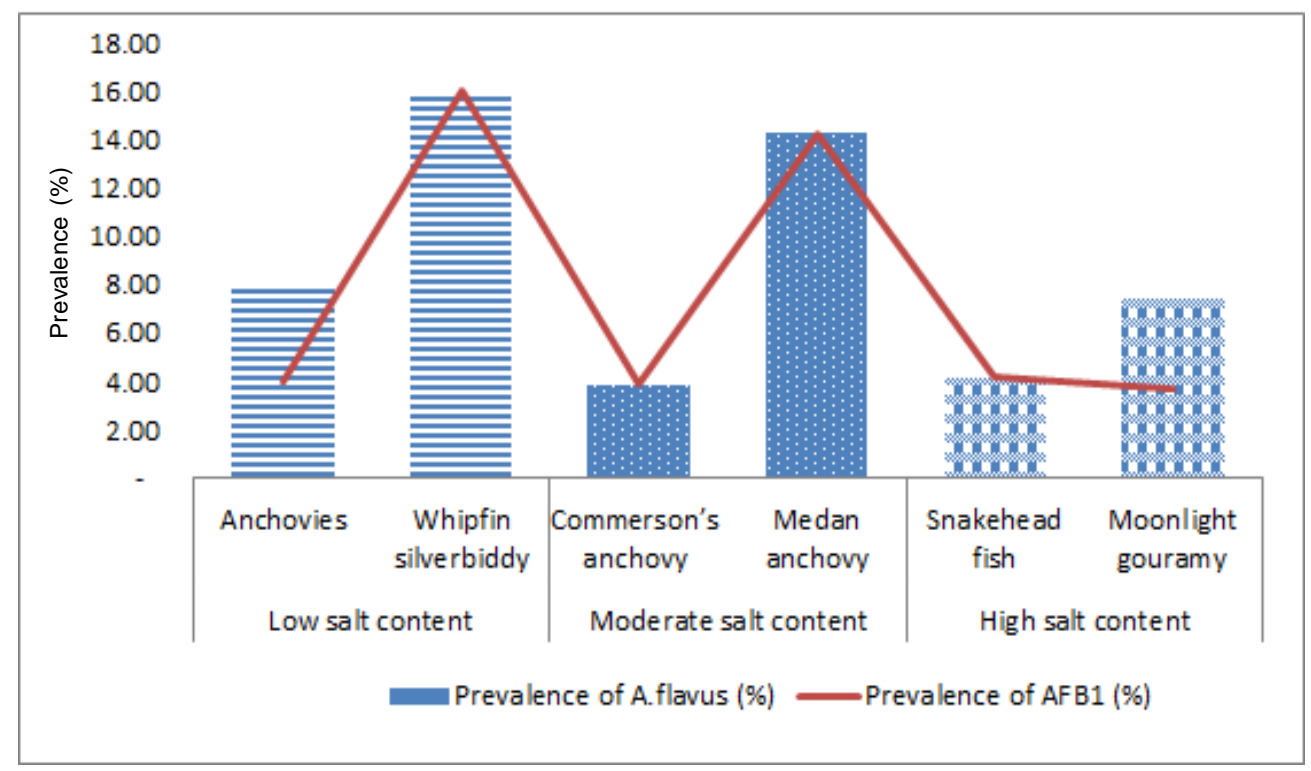

Figure 3. Correlation between prevalence of $A$. flavus dan AFB1 in sample.

Liu (2007) who stated that contamination can be happened during processing, storage and marketing. Another reason is probably because the dried salted fish were arranged in a high pile during retailing. It will make the pile of fish raise in temperature and humidity that allows mould to grow. Jurjevic, Wilson, Wilson and Casper (2007) revealed that during storage, mould population and the production of aflatoxin rose in the supportive environment. Dried fish handling at level of wholesaler is usually better than at retailer, in which dried fish was put in boxes or cartoons. Some wholesalers also stored the dried fish in cold storage. However, in this study we found A.flavus identified in dried salted fish which was obtained from a wholesaler who did not have cold storage facilities.

The prevalence of $A$.flavus on dried salted fish from East Java was higher compared to other regions (Figure 5). This is possibly due to the temperature and humidity in East Java are relatively high (32-
$33{ }^{\circ} \mathrm{C}, 45-55 \%$ ) which allows A.flavus to grow. Additionally, distribution rate of dried salted fish in East Java is slower than that in West Java, meaning that the level of consumption of dried salted fish in East Java population is lower than in West Java. In this study, there was no correlation between concentration and prevalence of $A$. flavus, especially on medium and high salt levels. This is likely due to the growth of $A$. flavus influenced by the concentration of salt. Attapattu \& Sarajeewa (1990) reported that the growth of A.flavus was inhibited in salt concentration of $>10 \%$. It seems that there was a positive correlation between $A$. flavus and AFB1 on dried fish with low and moderate salt content, but it was negative in high salt content.

\subsection{Relationship Between Moisture Activity, A. flavus, AFB1 and Total Mould Count}

The relationship between moisture activity, $A$. flavus, flatoxin B1 and total mould can be seen in 


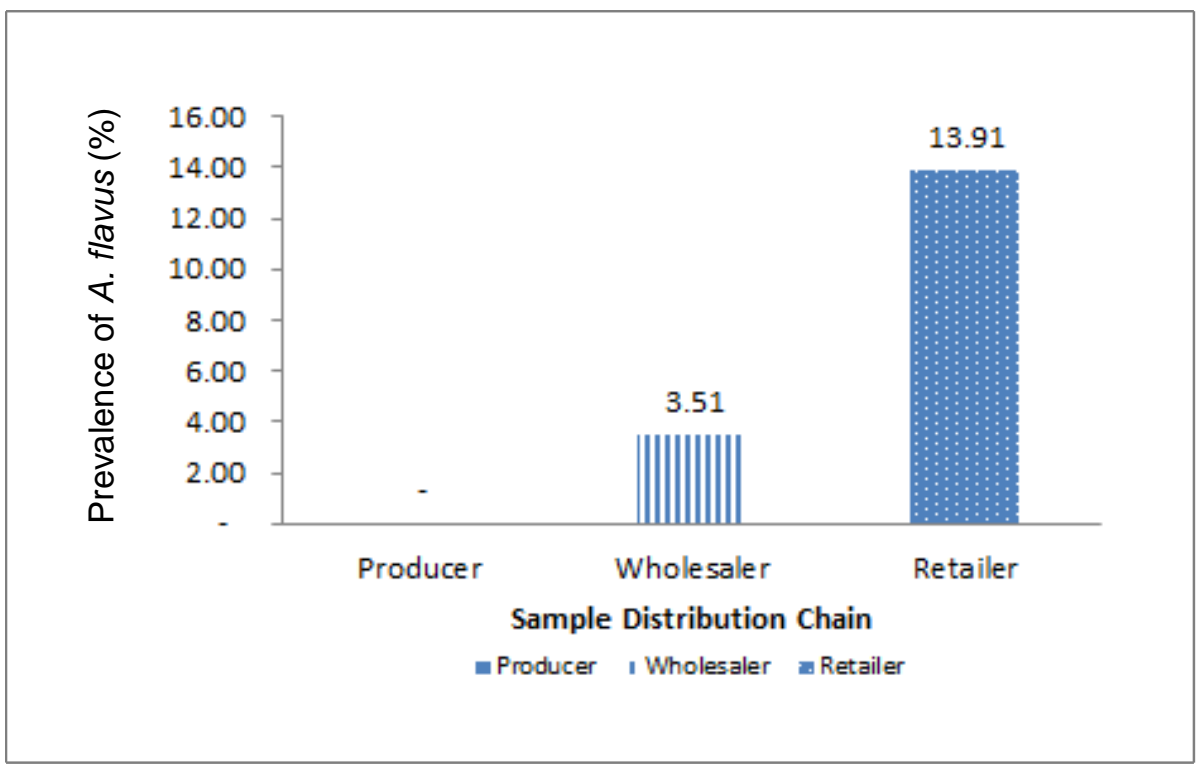

Figure 4. Prevalence of $A$.flavus based on dried fish distribution chain.

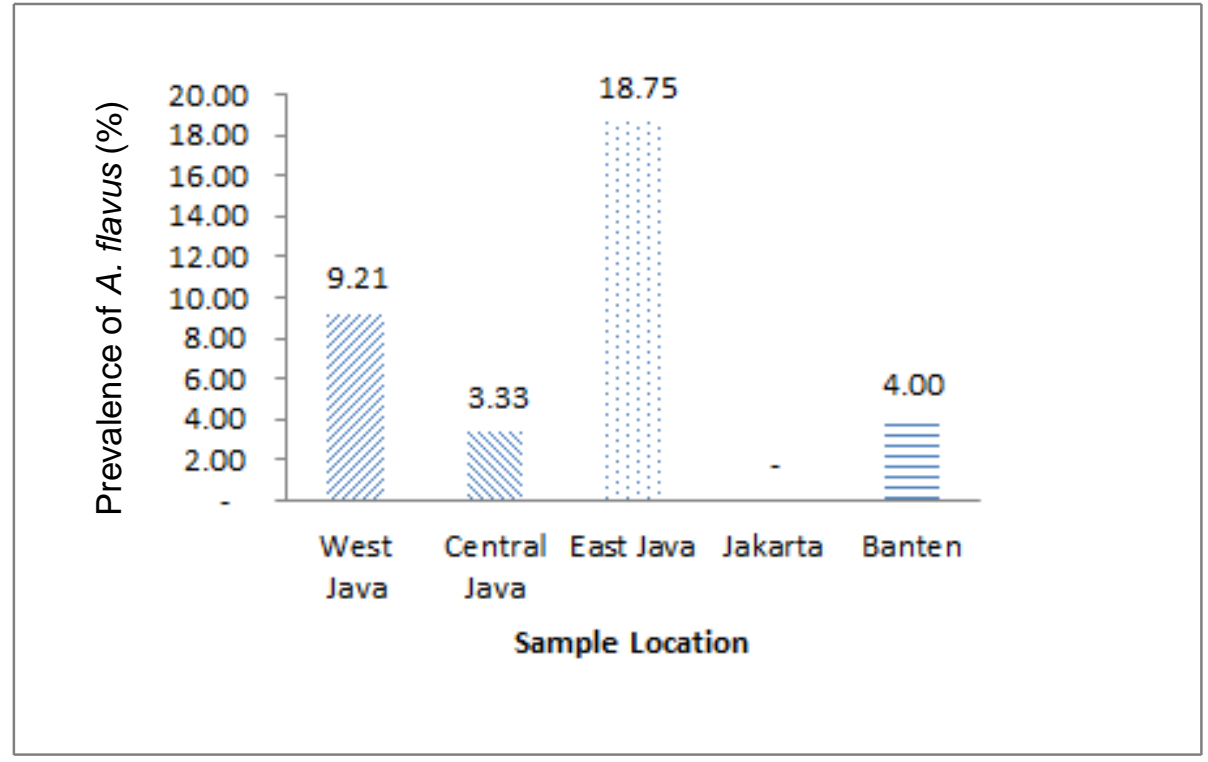

Figure 5. Prevalence of $A$.flavus based on sample locations.

Table 3. Environmental conditions at storage sampling point of dried salted fish

\begin{tabular}{lcc}
\hline Sample Location & Temperature $\left({ }^{\circ} \mathrm{C}\right)$ & Humidity $(\%)$ \\
\hline Banten & $33.6-34$ & 46 \\
DKI Jakarta & 31 & 55 \\
West Java & $29-34$ & $40-76$ \\
Central Java & $31-32$ & $54-55$ \\
East Java & $32-33$ & $42-55$ \\
\hline
\end{tabular}




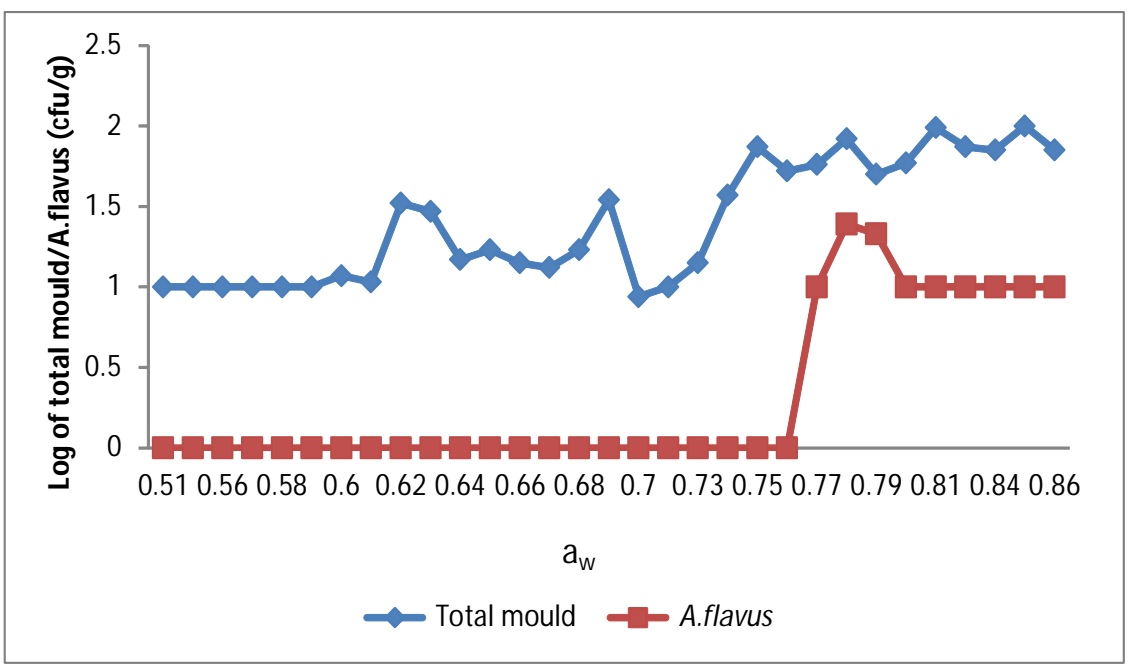

Figure 6. The effect of water activity on total mould and A. flavus.

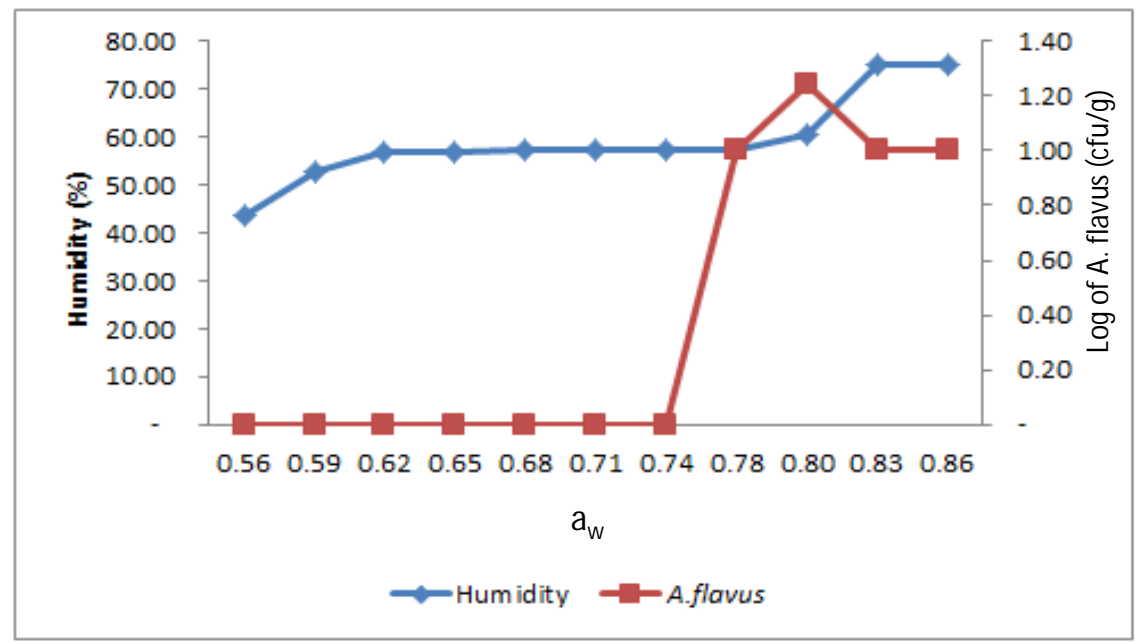

Figure 7. The effect of humidity and water activity on the growth of $A$. flavus.

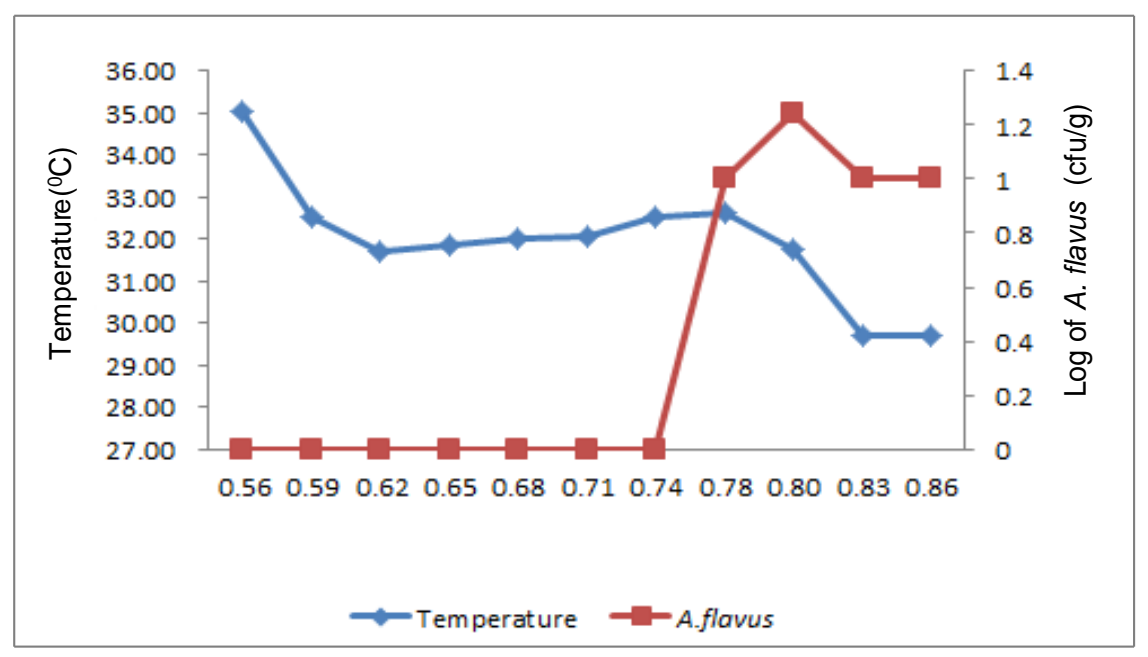

Figure 8. The effect of temperature and water activity on the growth of $A$. flavus. 


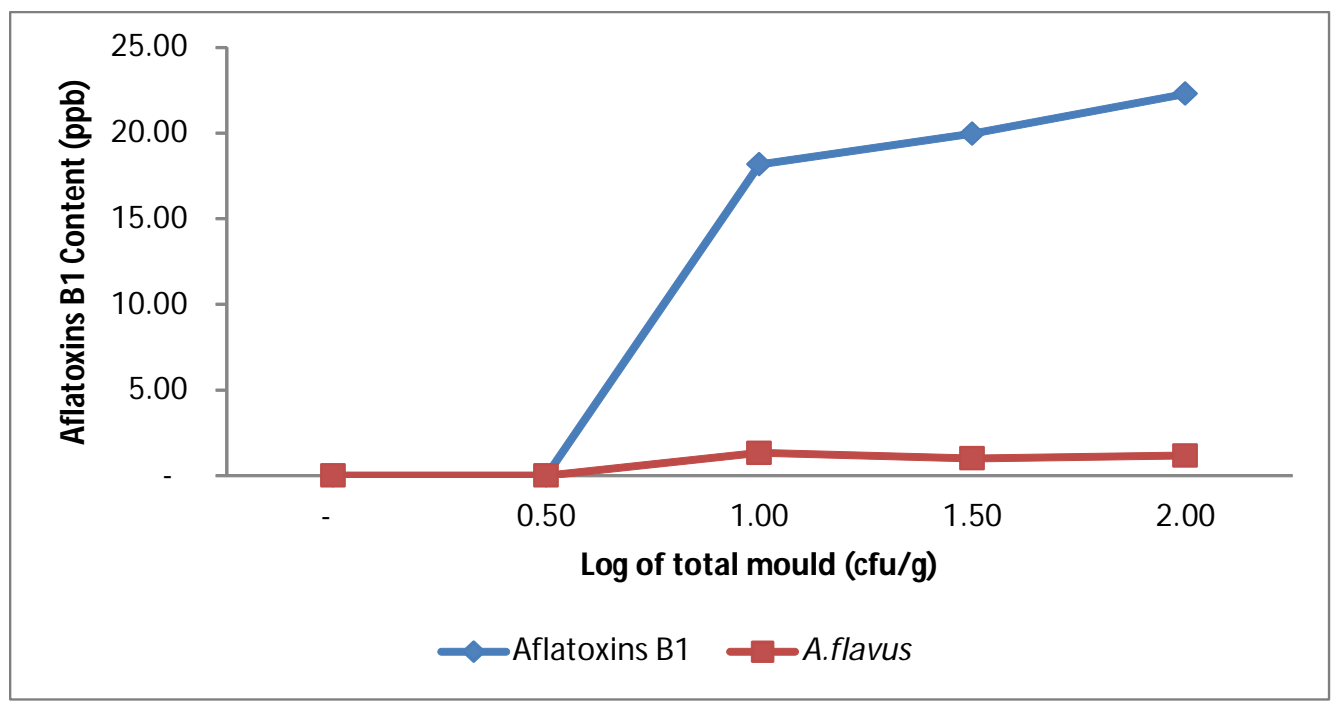

Figure 9. Correlation of total mould, A. flavus and AFB1.

Figure 6. Mould can grow on a wide range of $\mathrm{a}_{\mathrm{w}}$ values i.e $0.51-0.86$. The higher the value of $\mathrm{a}_{w}$ then the mould will increased in number. The growth of $A$. flavus started at $\mathrm{a}_{\mathrm{w}}$ of 0.78 , and the amount increased at $\mathrm{a}_{\mathrm{w}}$ of $0,82-0.84$. A. flavus began to produce AFB1 at $\mathrm{a}_{\mathrm{w}}$ of 0.78 and increased until $a_{w}$ of 0.84 . There was similar pattern between the production of total A.flavus and the amount of AFB1 produced. According to Ahmad (2009) temperature and humidity of environment and also the length of storage were factors supporting mould contamination and aflatoxin production.

\subsection{Relationship between Humidity and Temperature to the Growth of $\boldsymbol{A}$. flavus}

Correlation between the environmental humidity (Figure 7) and the temperature (Figure 8) of A. flavus growth are significant. The increase of $A$. flavus growth in line with the increase of environmental humidity and the decrease in temperature. In this study, A.flavus grew at temperature of $29-35^{\circ} \mathrm{C}$ and $59-76 \%$ humidity. Pitt \& Hocking (2009) reported that $A$. flavus produces aflatoxin at $13-37^{\circ} \mathrm{C}$ and $\mathrm{a}_{\mathrm{w}}$ of 0,78 .

Figure 9 shows the correlation between total mold, A.flavus and AFB1. A. flavus grew when the total mould reached log $1.0 \mathrm{cfu} / \mathrm{g}$ and remained stable until the total mould reached log $2.0 \mathrm{cfu} / \mathrm{g}$. In contrast, the concentration of AFB1 tended to increase. These may happened because of the environment condition such as temperature and $a_{w}$ supported the production of AFB1.

\section{Conclusion}

From this study, it can be drawn a conclusion that dried fish which was contaminated with $A$. flavus can produce AFB1. The dried fish were contaminated with A. flavus at temperature of $25.2-32.2^{\circ} \mathrm{C}, 65-84 \%$ humidity, $17-50 \%$ moisture content, $0.25-19.88 \%$ salt content, and $0.73-0.86 \mathrm{a}_{\mathrm{w}}$. The prevalence of $A$. flavus in whipfin silverbiddy (low salt content) was the highest $(16 \%)$ compared to medium and high salt concentrations with log concentration of $1.51 \mathrm{cfu} / \mathrm{g}$. This condition indicates that salt content has an effect on the growth of $A$. flavus. The prevalence of $A$. flavus in dried salted fish was $9.33 \%(14 / 150)$ while the prevalence of AFB1 was $8 \%$ (12/150) with detectable concentrations of $10.71-33.6 \mathrm{ppb}$.

\section{References}

AOAC. (2000). Official Methods of analysis. Association of Analytical Chemist. Washington DC. 1018p

Ahmad, R. Z. (2009). Mold contamination on feed and its controll. J. Litbang Pertanian 28(1): 15-22

Aisyah, S., Safika, \& F. Jamin Aisyah, S. (2015). Determination aflatoxin B1 in processed peanut feed using Enzym-Linked Immunosorbent Assay (Elisa). Jurnal Ked. Hewan. 9(1)

Atapattu, R. \& Samarajeewa. (1990). Fungi associated with dried fish in Srilanka. Mycopathologia 111: 5559

Ayejuyo, O.O., Olawu, R.A., Agbaje, T.O., Atamenwan, M. \& Osundiya, M.O. (2011). Enzyme-Linked Immunosorbent Assay (ELISA) of aflatoxin B1 in Groundnut and Cereal Grains in Lagos, Nigeria. Research Journal of Chemical Science 1(8): 1-5

BSN. (2009). Microbiological test method part 7: Determination of mold and yest on fisheries products. SNI 2332.7.2009. National Standardization Board.

BSN. (2006). Chemical Test Method Part 2: Determination of moisture content in fishery products. SNI 01-2354.22006. National Standardization Board. 
BSN. (1991). Determination of Salt Content in fishery product. SNI 01-2359-1991. National Standardization Board.

Basmal, J., Indriati, N., Hak, N, \& Nasran, S. (1999). Natural woodfish fermentation (arabushi) skipjack (Katsuwonus pelamis) and tuna (Auxis thazard) in desiccator. J. Pen. Perikanan Indonesia 5(2): 58-67

Chiou, C.H., Miller, M., Wilson, D.L.,Trail, F. \& Linz, J.E. (2002). Chromosomal location plays a role in regulation of aflatoxin gene expression in Aspergillus parasiticus. Appl. Environ. Microbiol., 68:306-315.

Chun H.S., Kim H.J., Ok. H.E., Hwang J. \& Chung, D. (2007). Determination of aflatoxin levels in nuts and their products consumed in South Korea. Food Chemistry $102:$ :385-391

Corry, J.E.L., Curtis, G.D.W., and Baird, R.M. (2003). Handbook of Culture Media for Food Microbiology Volume 37. $678 \mathrm{pp}$

Dharmaputra, D. S., Putri, A.S.R., Retnowati, I. \& Ambarwati, S. (2013). Aspergillus flavus and aflatoxins in peanuts at various stages of delivery chain in Pati Regency, Central java. Report of ACIAR Project PHT 1997/017. Nusa dua, Bali, $38 \mathrm{p}$

Didwaina, N. \& Joshi, M. (2013). Mycotoxins: A critical review on occurrence and significance. Int. J. Pharm. Pharm. Sci 5(3): 1014-1019

Duniaji, A.S., Hapsari, M.I.A. \& Puspawati, N.N. (2016). Potential of Aspergillus parasiticus in producing aflatoxin B1 in maize flour during storage. Media Ilmiah Teknologi Pangan 3(1): 35-42

Gunterus, A., Roze L.L., Beaudry, R. \& Linz, J.E. (2007). Ethylene inhibits aflatoxin biosynthesis in Aspergillus parasiticus grown on peanuts. Food Microbiology, 24: 658-663

ICMSF. (1996). Microoraganism in Food 5-Microbiological Specification of Food Pathogens. Blackie Academic and Professional, London. 514 pp.

Indriati, N., Wibowo, S., Yennie, Y., Kusmarwati, A., Hermana, I., \& Rahayu, E.S. (2015). Inventory and Identification of mould on Salted Fish, Smoke Fish and Boiled Salted Fish. Technical Report. Research and Development Center for Marine and Fisheries Product Processing and Biotechnology. $30 \mathrm{pp}$.

Indriati, N., Wibowo, S., Kusmarwati, A., Hermana, I., Hidayah, I., \& Rahayu, E.S. (2016). Risk Profile of Mycotoxins In Fishery Products. Technical Report. Research and Development Center for Marine and
Fisheries Product Processing and Biotechnology. $30 \mathrm{pp}$.

Indriati, N., Supriyadi, M.W. \& Salasa, F.F.A. (2008). Isolation and Identification of fungi on the skipjack boiled salted fish (Euthynnus affinis). J. Pascapanen dan Bioteknologi Kelautan dan Perikanan 3(1): 1119

Ismail, S.A.S. (2013). Control of xerophilic mould in traditional Egyptian salted fish, "Molouha". Departement of Food Hygiene and Control. International Food Reseach Journal 20(4): 18271831

Jurjevic, Z., Wilson, J.P., Wilson, D.M. \& Casper, H.H. (2007). Changes in fungi and mycotoxins in pearl millet under controlled storage conditions. Mycopathologia 164: 229-239

Makfoed, D. (1993). Food mycotoxin. Center University of Food and Nutrition, Gajah Mada University. Kanasius, Yogyakarta. 678 pp.

Mishra, H.N. \& Das, C. (2003). A review of biological control and metabolism of aflatoxin. Critical Rev. Food Sci. Nurit. 43(3): 245-264

Safika. (2008). Correlation A. flavus with aflatoxin B1 concentrations in wood fish. J. Kedokteran Hewan 2(2): $170-175$

Pitt, I.J. \& Hocking, A.D. (2009). Fungi and Food Spoilage. $3^{\text {rd }}$ Ed. Springer, New York: $519 \mathrm{p}$

Pitt, I.J. \& Hocking, A.D. (1997). Fungi and Food Spoilage $2^{\text {nd }}$ ed London: Blackie Academic and Professional

Pitt, J.I., Hocking, A.D., \& Glenn, D.R. (1983). An Improved medium for detection of AFPA. J. Appl. Bacteriological 54: 109-114

Rahayu, E.S., Sardjono, \& Samson, R.A. (2014). Filamen Mold on Food. PT. Kanisius. Yogyakarta. 284 pp.

Rahayu, W.P. \& Khotimah, K. (2010). Regulation and Harmonization Mikotoksin analysis method. Delivered on Forum Group Discussion Aflatoxin From Indonesian V. Yogyakarta, 21 Desember 2010.

Wang, J. \& Liu, X. (2007). Contamination of aflatoxin in different kinds of foods in China. Biomed. Environment. Sci. 20: 483-487

Wheeler, K.A.. Hurdman, B.E., \& Pitt, J.I. (1991). Influence of $\mathrm{pH}$ on the growth of some toksigenik spesies of Aspergills, Penicillium and Fusarium. Int. J.Food Microbiol 12: 141-150

Yenny. (2006). Aflatoksin dan Aflatoksikosis pada Manusia. Universa Medicina 25(1): 41-52. 